Original scientific paper

UDK: 316.774:327(4)(324)

DOI: $10.5937 /$ jrs $15-25918$

Received: 21 February 2020 / Accepted: 31 March 2020

\title{
Constructing the Muslim Threat: A Critical Analysis of Marine Le Pen's Twitter Posts During the 2017 French Election Campaign
}

\author{
ADIS MAKSIĆ* \\ International Burch University, Bosnia and Herzegovina \\ NIHAD AHMIĆ*** \\ International Burch University, Bosnia and Herzegovina
}

\begin{abstract}
In recent years, the radical right-wing has been gaining ground in international politics. This analysis seeks to advance scholarly understandings of a major theme of right-wing discourse in Europe, the portrayal of Muslims as a threatening ethnoreligious other. It focuses on the Twitter activity of Marine Le Pen, the leader of the French right-wing National Rally (called National Front at the time) and former presidential candidate. Building on original research that extracted hundreds of tweets posted during the 2017 French presidential elections campaign, the study subjects 110 most popular tweets to a critical analysis. It shows that Le Pen's discourse worked to amplify prejudices and existential fears in ways that could appeal both to the radicals and the mainstream, thus creating demand for a national saviour.
\end{abstract}

Keywords: Marine Le Pen, National Front, Islamophobia, 2017 French Elections, Right-Wing Discourse

\section{Introduction}

Over the past decade, radical right-wing politics has been gaining ground in the international political terrain. The political parties with a populist, nativist and ethno-nationalist agenda have scored major electoral successes, while informal movements intensified street protests and online activism. The dominant political issues of the increasingly globalized world, such as immigration, international terrorism, erosion of state sovereignty and global economic crises, have served as axes of convergence between the diverse radical right-wing agents in Europe and the United States, turning them into a transnational political force.

At the very core of the radical right's political discourse in Europe is the portrayal of Muslims as a threatening ethnoreligious other, and Islam as a profane religious adver-

\footnotetext{
*adis.maksic@ibu.edu.ba

*"nihad.ahmic@stu.ibu.edu.ba
} 
sary. Islamophobia, or the visceral opposition to and prejudice against the Islamic religion or its adherents, has been on the rise across Europe along with the radical right. Even mainstream has become less liberal when it comes to Islam, as evidenced in the rising popular opposition to the building of minarets in several European countries. ${ }^{1}$ This shift in political discourse has been, in part, a reaction to the issues that have become dominant in global politics over the last two decades. Islamic extremism was at the heart of major terrorist events, from 9/11 and al-Qaida's subsequent attacks across Europe to the rise of ISIS. More recently, the European migrant crisis developed as a result of large-scale migration from the Muslim-majority countries.

Yet, there is never a one-to-one correspondence between the developments in the world and our perceptions of it. Opinion polls suggest that despite the efforts of extremist organizations, such as Al Qaeda and ISIS, most Muslims reject violence and terror. The majority of those who live in Western societies are loyal citizens of their states. ${ }^{2}$ Islamophobia, then, is not so mucha reaction to objective conditions as it is a discourse that creates blanket prejudices. Here the actions of a few are taken out of their proportions and used as resources for the demonization of the many.

Indeed, an understanding of the rise of Islamophobia in Europe requires that we approach it as a discourse and examine its performative structures. Many scholars have explored the rise of anti-Muslim messages across Europe, discussing it in the context of the social and political conditions that fuelled the gains of the political right. Mondon and Winter thus observe that the shockwaves of the 2015 Charlie Hebdo attacks brought together liberals and the conservatives across Europe and the United States into the stigmatization of Islam and Muslims. ${ }^{3}$ In their subsequent work, Mondon and Winter make an effort to distinguish between liberal and illiberal Islamophobia, showing that the former operates to stigmatize Muslims within the discourse of secularity and individual rights, as opposed to deterministic racism of the latter. ${ }^{4}$

Other authors discuss Islamophobic messages in the wider context of populist discourse. Reynie thus covers one major theme in National Front's Islamophobic discourse, the portrayal of Muslims as a threat to French culture and living standards, within the account of the rise of "heritage populism" across Europe. ${ }^{5}$ Maurer and Diehl quantitatively measure the use of anti-corporate, anti-political elite and anti-media signifiers during the campaigns of Le Pen and Emmanuel Macron in France, as well as Donald Trump and Bernie Sanders in the United States, to make comparative conclusions about populist

$1 \quad$ Kallis 2015.

2 Esposito 2019.

3 Mondon and Winter 2017a.

4 Mondon and Winter 2017b.

5 Reynie 2016. 
campaign styles. ${ }^{6}$ They find that Donald Trump most frequently deployed anti-media and anti-establishment signifiers, followed by Marine Le Pen, while Bernie Sanders relied on anti-corporate messages.

While these works certainly contribute to an understanding of the performative powers of Islamophobic discourse, they do so only indirectly. An analysis of Islamophobia is performed to the extent needed for the development of populism as a conceptual instrument. Whether it is the differentiation between illiberal and liberal populism, heritage populism or trans-Atlantic comparisons of populist styles, anti-Muslim and the related anti-elitist messages are categorized to build conceptual generalizations. While analytically useful, the breadth of these studies comes at the expense of understanding the depths of specific performative powers. The pages that follow attempt to step into this void by offering a case-specific analysis of an Islamophobic discourse that happened in a specific state, and at a politically sensitive time. The analysis examines the portrayals of Muslims that the leader of the French right-wing National Front, Marine Le Pen, constructed through her tweets during the 2017 election campaign. It offers an understanding of how the linguistic content of these acts interacted with staging, political contextuality and social structures to generate performative powers that worked to intensify prejudices against French Muslims. By using the discursive-affective framework, the analysis acknowledges and explores the emotional salience of Le Pen's discourse as a crucial aspect of its performativity. Taken together, the approach studies the political use of Islamophobia through an analysis of one of its major instantiations.

\section{Why Analyse Islamophobic Discourse?}

Over the last couple of decades, many theorists have exposed the power of language to construct reality. As Etelamaki observes, our perceptions emerge not through meanings that the world imposes on us, but through intersubjective social action that constructs meanings autonomous from any objective conditions. ${ }^{7}$ These socially constructed meanings, which inform human behaviour, are never fully fixed, and their survival requires constant linguistic production and reproduction. Language, then, constitutes subjectivities, which are maintained and redefined through continuous performative action. ${ }^{8}$

In its most general sense, the term discourse signifies this intersubjective field within which a multitude of linguistic and other semiotic activities clash and interact to create multiple realities. Moreover, discourse is a polyvalent analytic concept that is also conceptualized at other levels. While it may sometimes refer to all semiotic activity, at other times it signifies determinable groups of acts, or specific modes of understanding, that

6 Maurer and Diehl 2017.

7 Etelamaki 2016.

8 Cavanaugh 2015. 
inform human behaviour. ${ }^{9}$ Islamophobia, then, refers to groups of discursive acts that share interpretations of a particular phenomenon, even if their specific frames, narratives and discursive tactics differ. Yet, since the generated meanings are also dependent on these more specific tactics, as well as on political contextuality and speaker positionality, it is also useful to identify a distinct discourse in amore specific group of acts. We can thus speak not only of Islamophobia as a general discourse, but also of Islamophobia in Europe, state versus dissident Islamophobia, Islamophobia in the 19th century, and Islamophobia of Marine Le Pen.

Indeed, this conceptual understanding motivates the analysis of Marine Le Pen's discourse here. By recognizing the power of discourse to define problems, pose questions, produce perceptions and drive action, we recognize the National Front as an important agent that struggles to stabilize a particular view of Islam and Muslims amongst multiple discursive possibilities. The degree of such stabilization, in turn, is positively related to political power. The perceptions of Muslims as a threat to French security and identity rearrange power relations by opening a slot of a national saviour for the National Front.

A critical discourse analysis, which treats language as a form of social practice and relates it to the broader socio-political context, has the potential to expose linguistic action that constructs and reconstructs social structures and hegemonic understandings. In the words of Wodak, ${ }^{10}$ discourse analysis is "fundamentally concerned with analysing opaque as well as transparent structural relationships of dominance, discrimination, power, and control as manifested in language". This task is advanced by examining how discursive acts operate both explicitly and implicitly to mobilize sensibilities, generate meanings and produce political commitments. In this sense, Marine Le Pen's framing of Muslims and Islam during the 2017 election campaign will be analysed here as one attempt to rearrange the French landscape of collective identities.

Moreover, this analysis seeks to apply a discursive-affective framework for understanding the performative powers of Le Pen's discourse. ${ }^{11}$ Namely, it draws on the recent advances in the studies of human cognition to suggest that the discourses should be evaluated by the affects that they are able to generate. It acknowledges that the meanings emerge not in any "common sense" rationalist way but through subjective, or group-specific affective structures. This primacy of affects has been explored in recent years by scholars from diverse disciplines. Psychologist Drew Westen ${ }^{12}$ thus studied MRI scans to measure the brain activity of political partisans to suggest that when emotions and reason collide, emotions consistently prevail. A study by neuroscientist Antonio Damasio ${ }^{13}$ arrives at a similar conclusion. He argues that emotions and gut feelings participate even in those

\footnotetext{
9 Mills 2004, 6.

10 Wodak 2015.

11 Maksic 2019.

12 Westen 2007.

13 Damasio 2005.
} 
activities that seem exclusively rational, such as the cost-benefit analyses. Sensibilities first highlight some options and eliminate others before deliberative reasoning can take place. The lesson for the analysis here is that we should aspire to understand the affective qualities of Le Pen's tweets or the intensities and types of sentiments they mobilize and circulate to motivate political action. After all, Islamophobia, as the word itself implies, ultimately refers to an emotion.

\section{French National Front and the Rise of Islamophobia}

While the previous two decades have been marked with the increasingly negative perceptions of Muslims and Islam in Europe, the phenomenon is not new. Islamophobia shares deep historical roots with other forms of xenophobia, which are grounded in longstanding views of cultures as geographically bounded markers of essential difference. France occupies a special place in the history of political movements that advocate such worldviews, with some authors identifying their origins in opposition to the French revolution. ${ }^{14}$ Yet, mainstream political parties in France and elsewhere in post-war Europe have shown willingness to confront different forms of racial, ethnic and religious discrimination, successively maintaining the radical right at the political margins. In 1981, Jean Marie Le Pen, the founder of the National Front and father of Marine Le Pen, was not able to secure even 500 votes to run in presidential elections.

The rest of the 1980s, however, mark a period when the National Front began to register on the French political radar. In the 1986 legislative elections, the party won nearly 10 percent of the overall vote. ${ }^{15}$ The rise would carry over into the 1988 presidential elections, in which 14.4 percent of the voters cast ballots for Le Pen. ${ }^{16}$ This level of support would be maintained until the crisis of 1997 when one of the party's factions split to form the National Republican Movement. In the next decade, the party would struggle to reconsolidate support and recover from electoral defeats.

The party would begin its current resurgence with the retirement of Jean Marie Le Pen, and the 2011 election of Marine Le Pen as its new leader. Already in the 2012 Presidential Elections, Le Pen would gain 17.9 percent of votes, which was the best ever showing of the National Front. In the 2014 European parliament elections, the party won nearly a quarter of the votes. This success would continue into the 2017 presidential elections analysed here, in which Le Pen made the second round. Although Le Pen eventually lost to Emanuel Macron, the nearly 34 percent of the votes she received unambiguously signalled that the National Front grew into a major political force in France.

14 Benveniste and Pingaud 2016.

15 Shields 2007, 209.

16 Ibid., 224. 
What has changed in the Le Pen era to bring millions of new voters and thousands of new members to the National Front? A contrast between the leadership of Marine Le Pen and her father suggests that the Party indeed adjusted its message to attract more moderate voters. The former leader of the National Front advocated repatriation of legal immigrants, supported the death penalty and made occasional anti-Semitic comments. The Party's radicalism came into conflict with core principles of liberal democracy. In contrast, Marine Le Pen has softened the position on legal migration and death penalty and seeks to promote the party as the guardian of secular democracy.

While Le Pen has made a discursive stretch to expand the Party's appeal, she also ensured that this does not come at the expense of the more traditional supporters. In particular, the National Front remains the symbol of Islamophobia in France. The rising anti-Muslim and anti-immigrant sentiments across Europe are a rich reservoir of resources that Le Pen sought to amplify and transfer into new votes, even if balanced with the Party's rebranding efforts. Occasionally, this took the form of unsubstantiated claims of a cultural invasion, such as the statement that 100 percent of the meat sold around Paris was halal. ${ }^{17}$ More frequently, Le Pen interpreted the public presence of Islamic symbols and a way of life as an attack on French secularity. As Reynié ${ }^{18}$ puts it, the National Front now portrays itself as "the chief protectors of liberty, blaming the elite and the mainstream parties for failing to uphold the values and rules of liberal society and for being complacent about the rise of multiculturalism and Islamism".

Much of the recent successes of the National Front, then, can be attributed to a discursive shift. This suggests that discourse analysis holds great potential for understanding Le Pen's electoral performances. At the same time, the complexity of contemporary National Front discourse poses an analytical challenge, as it asks for a proper account of the diverse messages. Yet, the analytical reconciliation of their performative powers can tell a great deal about Le Pen's political powers.

\section{Why Analyse Tweets?}

The advent of social media networking sites, such as Twitter or Facebook, has broken down a barrier between the ones who provide information, and those who absorb it. Among these, Twitter has been the favourite social network of political leaders. Prime Minister of Canada, President of the United States of America, President of France and President of Mexico are just some of many important political figures who daily express their stances on the political situation in their countries and globally. Having a 280-character limit and hashtags as its trademark, Twitter allows politicians to produce many messages that could reach and actively engage with large audiences. Its architecture incentiv-

17 Mondon 2015.

18 Reynié 2016. 
izes the circulation of messages (e.g. hashtags) and motivates further circulation (e.g. by using retweet option).

In his work on using Twitter for social media campaigns in the USA, Enli argues that the contemporary "era of social media" is a distinct historical period of political communication. Since 2010, the increasing reliance on online networks has created a "power balance between politicians and editorial media". ${ }^{19}$ Social media networks have opened a new political terrain in which politicians directly and continuously communicate with potential voters from the comfort of their homes. In turn, comments, shares and retweets have created a sense of the newfound ability of mass audiences to participate in political discourse. The perceived distance between the elites and the public has been reduced at large.

Moreover, social media have worked to intensify the affective salience of political discourse and the relevance of populist communication style. Stieglitz and Dang-Xuan thus observe that Twitter rewards affectively charged messages, which "tend to be re-tweeted more often and more quickly compared to neutral ones". ${ }^{20}$ Similarly, Carrella concludes that emotional, simplistic or dichotomist messages, which are the main performative structures of populist discourse, seem to be more frequent in popular tweets when compared to non-popular ones. ${ }^{21}$ Carrella finds that even non-populist politicians increased the deployment of such messages when addressing the public through social media.

Twitter, then, has become a new political battleground. A major part of the battle for votes is now a fight for online followers. This is especially the case with far-right movements, whose recent rise from the political margins is in part due to the newfound ability to bypass editorial and governmental controls and directly communicate to the audiences through digital media. ${ }^{22}$ Moreover, Twitter has added significance when it comes to communicating Islamophobia. As Froio and Ganesh find, the far-right Twitter activity in general remains primarily intranational, but Islamophobic messages depart from this pattern, garner cross-national attention and serve as a "transnational glue" of right-wing activism. ${ }^{23}$

With so many people taking to Twitter and other social media to hear or even engage in political debates, the Online has become an indispensable terrain for political discourse analysis. When it comes to Le Pen's 2017 campaign, social media messages were her most important means to build a support base. The second round of the campaign saw a race between Emanuel Macron, a newcomer, and Le Pen, a relative outsider. Neither candidate was able to rely on well-established links with news organizations and had to broaden

19 Enli 2017.

20 Stieglitz and Dang-Xuan 2013.

21 Carrella 2018.

22 Albrecht et al. 2018.

23 Froio and Ganesh 2018, 101. 
their support base quickly. In these circumstances, both candidates saw large potential in an Internet-based campaign, and Twitter in particular. ${ }^{24}$

While these considerations point to the value of Twitter for the study of political discourse in general and Le Pen's Islamophobia in particular, such analysis is limited by several factors. The retweet count may be distorted by the presence of bots and mock profiles, and thus may not accurately represent the actual popularity of a tweet. Moreover, Twitter demographics diverge from the demographics of the general population. Half of its French users, for example, are between 25 and 39, while only 18 percent of the French population falls into this age category. ${ }^{25}$ Additionally, short texts allowed on Twitter create analytical challenges due to limited contextual information. In this circumstance, the analyst can explore the meanings of the small text content only through careful consideration of prior contextual knowledge.

\section{Le Pen's Othering of Muslims and Islam}

This analysis of Le Pen's discourse was performed with the aid of Twittonomy, which is an online tool for data analytics on the Twitter platform. Twittonomy provides access to the Twitter API, allowing researchers to collect all Twitter activity of a specific user. This includes tweets, retweets, replies, mentions and hashtags. For the purpose of analysing Le Pen's framing of Muslims and Islam during the 2017 election campaign, the data collection covered the period of one month prior to the election day, which was scheduled for April 23. For the period from March 23 until the election day, 887 tweets were collected, and the analysis was performed on the 110 most popular tweets determined by the number of favourites. Out of these, 29 tweets were found that explicitly referred to Islam and Muslims and are presented in Table 1.

\begin{tabular}{|l|c|}
\hline Tweets & Favorites \\
\hline $\begin{array}{l}\text { "I do not want to get used to Islamist terrorism [...] it's over with laxity, it's over with } \\
\text { naivety!" }\end{array}$ & 3293 \\
\hline $\begin{array}{l}\text { "With Russian President Vladimir Putin we have, among other things, discussed at length } \\
\text { the international situation and Islamist terrorism." }\end{array}$ & 2539 \\
\hline "Street prayers: I pledge to restore secularism and public order!" & 2479 \\
\hline "We must expel foreign imams who preach hatred and all the foreigners labelled by 'S card." & 2338 \\
\hline $\begin{array}{l}\text { "I spoke with President Putin about the fate of Eastern Christians, threatened daily by } \\
\text { "On the eve of the big annual gathering of radical Islamists organized by the \#UOIF, I claim } \\
\text { its prohibition!" }\end{array}$ & 2231 \\
\hline "We can't leave our children a country that is not able to defend them." \#ChampsElysées & 1998 \\
\hline "No, Mr. Macron, one cannot be a follower of radical Islam and a "good guy"” & 1856 \\
\hline "Street prayers are forbidden in our country and therefore the law must be enforced!” & 1416 \\
\hline $\begin{array}{l}\text { "I express my solidarity with the Swedish people, who have been touched by an odious, } \\
\text { probably Islamist, attack." }\end{array}$ & 1378 \\
\hline
\end{tabular}




\begin{tabular}{|c|c|}
\hline Tweets & Favorites \\
\hline $\begin{array}{l}\text { "Wars are won only by consistency and coherence. The war against Islamism does not } \\
\text { escape this immutable principle" }\end{array}$ & 1327 \\
\hline $\begin{array}{l}\text { "I have a muffled anger, not everything is done to put our compatriots at the shelter." } \\
\text { \#ChampsElysées }\end{array}$ & 1286 \\
\hline $\begin{array}{l}\text { "Tribute and condolences to the family of our soldier of the operation Barkhane, fallen in } \\
\text { the fight at \#Mali against the Islamists." }\end{array}$ & 1238 \\
\hline $\begin{array}{l}\text { "We must attack the ideology of this terrorism, which has been swarming with us for years." } \\
\text { \#ChampsElysées }\end{array}$ & 1237 \\
\hline "Hate preachers must be expelled, Islamist mosques closed." & 1188 \\
\hline $\begin{array}{l}\text { "The day after my election, I will immediately expel the foreigners labelled by S-card that } \\
\text { are a threat to our country." }\end{array}$ & 1168 \\
\hline "I have a feeling of sadness for our police forces who pay a heavy price." \#ChampsElysées & 1162 \\
\hline "Does Bashar al-Assad send soldiers to our streets to kill our children? No, Daesh does it." & 1133 \\
\hline "The \#burkini will be banned on all our beaches, it's an Islamist sign." & 1121 \\
\hline $\begin{array}{l}\text { "The financing of the mosques cannot, under any circumstances, be public or of foreign } \\
\text { origin." }\end{array}$ & 1048 \\
\hline $\begin{array}{l}\text { "I will never ask the French to get used to terrorism, I will put Islamic fundamentalism on } \\
\text { my knees!" }\end{array}$ & 1029 \\
\hline $\begin{array}{l}\text { "These Islamists have designated me as the candidate to lose, which proves that they have } \\
\text { understood who they should fear!" }\end{array}$ & 1000 \\
\hline "The Islamist ideology should not have the right of city in France." & 982 \\
\hline "Salafist organizations such as branches of the Muslim Brotherhood must be banned." & 996 \\
\hline "We must expel the foreign imams who preach hatred, we must expel the foreign Islamists!" & 994 \\
\hline "I demand the immediate expulsion of foreigners labelled by S-card." & 944 \\
\hline "I am the candidate of a firm secularism that rejects the claims of Islamist fundamentalism." & 922 \\
\hline $\begin{array}{l}\text { "Once again, the Copts are struck in their hearts, in their churches. Cooperation against } \\
\text { Islamist fundamentalism must be accentuated." }\end{array}$ & 914 \\
\hline $\begin{array}{l}\text { "I will fight against Islamist fundamentalism. At the university as elsewhere, no overt reli- } \\
\text { gious symbols!" }\end{array}$ & 511 \\
\hline
\end{tabular}

Table 1: Tweets that contain feelings expressed against Islam and, as Marine Le Pen puts it, Islamist ideology.

Each of the tweets above was subjected to qualitative analysis, in search of explicit and implicit meanings they circulated. In this manner, the analysis assessed their social function. Moreover, patterns were identified between tweets and analysed as the performative structures of the wider discourse. In search of meanings, it examined both logical connections between explicit statements and implicit connotations, as well as the sensibilities that the tweets mobilized and circulated. 
The analysis of tweets in Table 1 exposes several distinct performative structures that construct the social and political function of Marine Le Pen's portrayal of Muslims and Islam. Moreover, these structures can be grouped into two distinct sets. The first set describes the problem, while the second one offers the solution. Descriptively, Islam is seen as a threat to secular democracies. Beyond this attack on values and traditions, Islam, in its radical form, is framed as a source of terrorism and an urgent national security issue. This theme works together with Le Pen's standards for defining one as an extremist, which comes close to labelling Muslims more generally.

Furthermore, Le Pen takes every opportunity to express solidarity with not only other states in the European Union but also Orthodox Christians in the fight against Islamism. Here the National Front leader manifests what Rogers Brubaker has labelled as "civilizationalism" of national populist movements of Northern and Western Europe. ${ }^{26}$ While the nationalists, especially those of the Netherlands, France, Scandinavia, Belgium, Austria, and Switzerland, portray themselves as guardians of the Christian identity against the Islamic threat, this "Christianism" is a matter of belonging rather than faith. The nationalists are at the same time civilizationalists, insofar as the nation belongs on the Christian side of the civilizational divide between Christianity and Islam. Christianity is celebrated here not in theological terms, but as the "matrix of liberalism, secularity, and gender equality". ${ }^{27}$ Understood in the context of the wider liberal strand of Le Pen's Islamophobia, the tweets of solidarity with Orthodox Christians thus implicitly construct Muslims as the radical civilizational other.

The prescriptive themes build on this descriptive portrayal. Le Pen accuses her opponent in the presidential race as incompetent and unable to deal with the threat. Since the guardian is missing, the slot of a national saviour is opened up and seized by the National Front. The following pages discuss these various themes in greater detail.

\section{Describing the Muslim Threat}

The analysed tweets show Marine Le Pen's ability to "other" Muslims and Islam while remaining consistent with the National Front's reformed image of a guardian of secular democracy. In the French context, this means protection of laïcité, a traditional French concept of secularism whose roots date back to the French revolution. In tweets 3 and 9, she emphasizes her opposition to street prayers as infiltration of religion into the secular public sphere. While street prayers had been outlawed since 2011, Le Pen promises more strict measures in implementing it than the previous government. Toward this end, she uses "restore secularism" and "the law must be enforced" to suggest that her political opponent was complicit in corrupting the longstanding tradition upon which the French contemporary political identity had been built.

26 Brubaker 2017.

27 Ibid., 1212. 
The tweets 20, 27 and 29 also explicitly discuss Islam in the context of separation of religion and state, specifically emphasizing the opposition to the public use of religious symbols and public funds for religious purposes. In the last tweet, Le Pen distinguishes herself as "the candidate of firm secularism that rejects the claims of Islamic fundamentalism", which implicitly suggests that the opposing candidates were soft on the Islamic threat to laïcité. Taken together, these tweets show that a major theme of Le Pen's discourse is what Mondon and Winter call "liberal Islamophobia". This type of Islamophobia is "anchored in a pseudo-progressive narrative in defence of the rule of law based on liberal equality, freedom and rights". ${ }^{28}$ In contrast, "illiberal Islamophobia" is essentialist insofar as it does not make a distinction between a specific belief and the behaviour of individuals or groups. Since Muslims are innately Muslim, there is nothing they can do to prove their loyalty.

Le Pen's defence of laïcité, then, may seem explicitly liberal, but implicitly it nonetheless performs the xenophobic "othering". While her tweets avoid the essentialist readings of a "clash of civilizations", their specific targeting of Islam suggests a cultural clash in which the differences between Islam and the "West" are found in the basic values of free speech and secularity. It becomes questionable whether the Islamic and French cultures can coexist, which subtly turns every adherent of Islam into a potential threat to the French way of life. In this manner, Le Pen's performative juxtaposition of Islam and secularity camouflages the Muslim "threat". It not only appeals to the sentiments of the far-right but is also more acceptable to the mainstream, which is consistent with the National Front's reformed image. The fears and enmities toward Islam are thus mobilized and amplified in a manner designed to avoid the simultaneous mobilization of rival sensibilities of shame and dishonour that much of the French public associate with unambiguous racism.

Beyond the threat to the French political traditions, Le Pen's tweets are also marked by a portrayal of Islam as an existential danger. The most popular of the tweets in Table 1 performed this task by claiming that France was on its way of getting used to Islamist terrorism. Three days prior to the elections, an ISIS-inspired attack near Paris's Champs-Elysées that killed one policeman and injured two others created an opportunity for Le Pen to amplify the frame by anchoring it to the palpable concurrent event. In the aftermath, four of Le Pen's most popular tweets referred to the attack with hashtags \#ChampsElysées. Tweet 7 framed the danger most dramatically, seeking channel the anger and fears triggered by the attack into the concern of parents for their children, or in other words, for the society's most weak and vulnerable members.

Furthermore, these portrayals served as a foundation for Le Pen's policy proposals. The threat created a national security imperative and demanded the most decisive responses. Le Pen thus tweeted a demand for prohibition of the annual assembly of Union of Islamic Organizations in France (UOIF), an umbrella organization French Muslims that had existed since 1983, under the pretence that it includes radical Islamists. Her tweeted policy positions also included the expulsion of foreign imams and closure of Islamist mosques.

28 Mondon and Winter 2017b, 12. 
Moreover, Le Pen's demands to expel individuals listed on S card, which lists names of persons suspected to be a threat to national security, are more controversial than initially meets the eye. The S Card is a diverse list, composed of those "who have simply looked at jihadist websites or met radicals outside mosques, to those considered highly dangerous". ${ }^{29}$ By demanding a sweeping expulsion, Le Pen thus relies on fears to justify the policy that would violate due process of law for many individuals, which is nearly certain to include the innocent.

Taken together, these tweets frame the national security danger as coming from within the French society, akin to an infection that can be removed only through a radical treatment that takes with it healthy tissue. While it may seem that this national security theme refers specifically to radical Islamists rather than Muslims and Islam in general, the contextuality tells a different story. The theme acquires its performative function as part of Le Pen's larger discourse, in which the line between Islamism and Islam is blurry and permeable. Indeed, the National Front leader assumes the position of authority for making this distinction and does it in a way that does not limit the definition of Islamists to the advocates of violence and lawbreakers. This is seen in tweet 8, when Le Pen refers to Mohamed Saou, a member of Emanuel Macron's campaign who was asked to step down after a website published several of his controversial old Facebook messages. In one of the posts, Sau criticized the Charlie Hebdo newspaper's publishing of cartoons of Prophet Muhammed, which inspired a 2015 jihadist attack against the paper. In the aftermath Macron made a statement describing Saou, "a good guy" ${ }^{30}$ Le Pen quickly seized the opportunity to describe Saou as a radical Islamist due to his reference to Charlie Hebdo alone.

Le Pen, it thus appears, denies the possibility that one could simultaneously feel insulted over the cartoons and be a law-abiding citizen who rejects violence. Considering that the cartoons offended both radical and moderate Muslims, the conjecture implicitly works to spread the sentiments of fear and distrust in a categorical manner. Everyone who bears marks of an adherent of Islam is suspected of harbouring sympathies for violent extremists. Similar work is performed by Le Pen's tweet regarding the prohibition of burkinis. While the prohibition of burkas and related outfits extends beyond the right-wing discourse, with many French towns and even some Muslim majority states outlawing it, Le Pen's tweet is notable for the linkage with radical political Islam. The more mainstream explanations for the prohibition cite practical security concerns (face recognition) and separation of the private and public sphere. In contrast, Le Pen frames it as a symbol of the ideology that represents the national security issues, implying that all Muslims who practice it, which are not limited to violent radicals, might pose an existential threat.

Moreover, Le Pen sometimes juxtaposes Islamism and terrorism in ways that blur the distinction between the two. An example is tweet 21, in which a single sentence initially speaks of terrorism in general, only to refer to Islamic fundamentalism. The implications

29 The Economist 2015.

30 Byrne 2017. 
are both qualitative and quantitative. Qualitatively, Islamism infiltrates the concept of terrorism so that it raises the question of whether other types of terrorism exist at all. Indeed, nowhere in the analysed tweets is there an acknowledgement of any terrorism other than that which is related to the Islamic religion. This has quantitative implications since it sets up contextuality for understanding the performative function of several additional tweets that refer to terrorism in general without mentioning Islamism in particular. Considered in this contextuality, these tweets become highly relevant for understanding Le Pen's circulation of Islamophobia in April of 2017.

Another set of tweets constructs national and religious solidarities so that Islam emerges as the radical civilizational other. Le Pen utilizes here the Islamist attacks in other Western European countries and against Christians elsewhere that were occurring at the time of the French election campaign. In tweets 2 and 5, she communicates support for Russia in its struggle against Islamism, portraying herself as a responsible leader who coordinates strategies with Russian president Vladimir Putin to keep France safe. In tweet 28, she expresses solidarity with Egyptian Copts after the April 9, 2017 bombings of their two churches in Egypt, calling for wider coordination in the fight against radical Islam. In tweet 10, she sends condolences to Sweden, in a swift reaction to the April 7, 2017 truck attack in Stockholm that murdered five people.

While these reactions would stir little controversy on their own, their function in the "othering" of Muslims emerges after considering the wider discursive context. What is omitted matters here as much as what is said. Namely, Le Pen does not mention attacks against the primary targets of Islamists - other Muslims. Le Pen seemed not to attach any significance to Islamist attacks against Muslims who did not share their interpretation of Islam, which were in spring of 2017 occurring on a daily basis and taking thousands of lives. This selection works to constructs the supra-confessional civilizational binary between Christians and Muslims as the overarching political cleavage. The French are instructed to feel the sentiments of compassion only with people on their side of the binary. Such selection served to break the links of solidarities with large majorities of Muslims, and French Muslims in particular, who opposed the violence of radical fundamentalists. Considered in its contextuality, this set of Le Pen's tweets thus joined in the categorical generalization of Muslims as the perfect opposition to what French society should look alike.

\section{From Threat to Saviour}

This section looks at the performative tactics through which Le Pen builds on the description of the Muslim threat to frame herself as the national saviour. The initial step in this move is to portray her political opponents as complicit in the rise of Islamism and incapable of protecting the country. Indeed, numerous tweets serve this purpose. The first and the most popular tweet thus describes the existing government as lax and naïve, in opposition to which the National Front emerges as vigilant and clever. Two of the tweets in the wake of the Champs Elysees attacks specifically target the government's incompe- 
tence. While ostensibly about the future, tweet 7 suggests that the current government has failed in performing the fundamental task of protecting its people. In tweet 12, Le Pen is more explicit, expressing anger that it was not being done enough to protect the citizens. She thus takes advantage of the attacks to channel the spike in anxieties toward displeasure with her political opponents.

This theme of laxity and incompetence is specified in several of Le Pen's tweets that target specific policy issues. In tweet 18 , she criticized the previous administration for calling on the removal of the authoritarian Syrian regime of Bashar Al Assad, who had been at war with radical Islamists. For Le Pen, human rights violations of Al Assad cannot be put above French national security. Here she echoes realism of Donald Trump's "America First" discourse, rejecting foreign policies that promote liberalism outside of the French borders and emphasizing the protection of the society within them. Similarly, in Le Pen's view, the naïve liberal hope of creating a safer world with the spread of democracy puts the French people into an existential danger.

Le Pen's construction of Islam and Muslims as a threat to both fundamental French values and physical security, coupled with the framing of the mainstream French politicians as lax, naïve and incompetent, opens the slot of a brave guardian who would save France from the jaws of a dangerous villain. While the amplified dramaturgy in the descriptive narrative intensifies the anxieties, the saviour is there to alleviate them. Here Le Pen constructs herself as the harbinger of this relief, with tweets 21 and 22 being the most explicit manifestations of this self-frame. In the former, Le Pen states that she will "put Islamic terrorism on its knees". In the latter, she suggests that Islamists desire her loss in the elections because the villain is intimidated by her capabilities and decisiveness. In this manner, Le Pen's discourse draws its performative powers from existential anxieties, which adds affective salience to the subsequent self-frame of a national saviour.

\section{Conclusion}

This analysis of Marine Le Pen's 2017 campaign tweets has revealed the discursive tactics though which the National Front continues to mobilize, promote and direct resentment towards Islam and Muslim. In order to maintain the Party's reformed image and reach the broader public, this Islamophobia now occurs behind a cosmetic reframing. Le Pen thus explicitly speaks of defence of laïcité, and protection against Islamist terrorism. At the same time, contextuality and framing ambiguities perform the implicit work of creating an open enmity against an entire category of people, their symbols, culture and religion. Whenever Islam is mentioned, the language of exclusion (expelling, closing, forbidding, banning, rejecting, fighting, etc.) is almost certain to follow.

It is also informative that more than a quarter of Le Pen's most popular tweets extracted for the purpose of this research explicitly address the Muslim other. If we count the tweets about terrorism and national security issues which contextually and implicitly refer to 
Islam and Muslims, this number goes up to over one half. Taken together, both the quantitative and qualitative aspects of Le Pen's campaign discourse indicate that the National Front leader's primary tactic is to discursively amplify existential fears, as well as the resentments over the alleged erosion of traditional French values. As these emotions increase, so does the opportunity for Le Pen to portray herself as the national saviour. Since each terrorist attack serves this affective purpose, and each Le Pen's discursive backlash contributes to the radicalization of Muslims, the French radical right and the radical Islamists appear to be the opposing parts of the same resonance machine. 


\section{References}

Twitter, Inc. (n.d.). Retrieved from https://investor.twitterinc.com/

The Economist. 2015. "A Bloody Siege Shows the Strengths and Limits of French Security Work", November 18. Accessed January 10, 2020. https://www.economist. com/europe/2015/11/18/a-bloody-siege-shows-the-strengths-and-limits-of-frenchsecurity-work

Albrecht, Stephen, Maik Fielitz, and Nick Thurston. 2018. "Introduction." In PostDigital Cultures of the Far Right. Online Actions and Offline Consequences in Europe and the US, edited by Fielitz Maik, and Nick Thurston, 7-25. Bielefeld: transcript Verlag.

Benveniste, Annie, and Etienne Pingaud. 2016. "Far-Right Movements in France: The Principal Role of Front National and the Rise of Islamophobia." In The Rise of the Far Right in Europe, edited by Gabriella Lazaridis, Giovanna Campani, and Annie Benveniste, 55-79. New York: Palgrave Macmillan.

Brubaker, Rogers. 2017. "Between Nationalism and Civilizationism: The European Populist Moment in Comparative Perspective." Ethnic and Racial Studies 40 (8): 1191-1226.

Byrne, Clare. 2017. "France's Le Pen Accuses Rival Macron of Being Soft on Islamists." The Times of Israel, April 15. Accessed January 11, 2020.

https://www.timesofisrael.com/frances-le-pen-accuses-rival-macron-of-being-softon-islamists/

Carrella, Fabio. 2018. "Analysis of The Correlation Between Populist Discourse and Tweet Popularity." Colloquium: New Philologies 3: 27-50.

Cavanaugh, Jillian. 2015. Performativity. Oxford: Oxford University Press.

Damasio, Antonio. 2005. Descartes' Error. New York: Penguin Books.

Enli, Gunn. 2017. “Twitter as Arena for the Authentic Outsider: Exploring the Social Media Campaigns of Trump and Clinton in the 2016 US Presidential Election."European Journal of Communication 32 (1): 50-61.

Esposito, John. 2019. "Islamophobia and Radicalization: Roots, Impact and Implications." In Islamophobia and Radicalization: Breeding Intolerance and Violence, edited by John Esposito, and Iner Derya, 15-33. New York: Palgrave Macmillan. 
Etelamaki, Marja. 2016. "Introduction: Discourse, Grammar and Intersubjectivity." Nordic Journal of Linguistics 39 (2): 101-112.

Fraisier, Ophélie, Guillaume Cabanac, Yoann Pitarch, Romaric Besancon, and Mohand Boughanem. 2017. "\#Élysée2017fr: The 2017 French Presidential Campaign on Twitter." International Conference on Weblogs and Social Media (ICWSM 2018), June 2018, Stanford, California, USA.

Froio, Caterina, and Bharath Ganesh. 2018. "The Far Right Across Borders Networks and Issues of (Trans)National Cooperation in Western Europe on Twitter." In PostDigital Cultures of the Far Right. Online Actions and Offline Consequences in Europe and the US, edited by Maik Fielitz, and Nick Thurston, 93-107. Bielefeld: transcript Verlag.

Kallis, Aristotle. 2015. "Islamophobia in Europe: The Radical Right and the Mainstream”. Insight Turkey 17 (4): 27-37.

Maksic, Adis. 2019. "Contemporary Ethnic Politics and Violence." In The Palgrave Handbook of Ethnicity, edited by Steven Ratuva. New York: Palgrave Macmillan.

Maurer, Peter and Trevor Diehl. 2017. "What kind of populism? A comparison of Marine Le Pen's and Donald Trump's Tweets in the French and US election campaigns of 2016/2017". Paper Presented at the 113th Meeting of the American Political Science Association, San Francisco, CA, August 2017.

Mills, Sara. 2004. Discourse: The New Critical Idiom. Routledge.

Mondon, Aurelien. 2015. "The French secular hypocrisy: The Extreme Right, the Republic and the Battle for Hegemony." Patterns of Prejudice 49 (4): 392-413.

Mondon, Aurelien, and Aaron Winter. 2017a. "Charlie Hebdo, Republican Secularism and Islamophobia." In After Charlie Hebdo: Terror, Racism and Free Speech, edited by Gavan Titley, Des Freedman, Gholam Khiabany, and Aurelien Mondon, 31-46. London, UK: Zed Books.

Mondon, Aurelien, and Aaron Winter. 2017b. "Articulations of Islamophobia: From the Extreme to the Mainstream”. Ethnic and Racial Studies 40 (13): 2151-2179.

Reynie, Dominique. 2016. “The Specter Haunting Europe: 'Heritage Populism' and France's National Front." Journal of Democracy 27 (4): 47-57.

Shields, James. 2007. The Extreme Right in France: From Pétain to Le Pen. London: Routledge. 
Stieglitz, Stefan, and Lihn Dang-Xuan. 2013. "Emotions and Information Diffusion in Social Media - Sentiment of Microblogs and Sharing Behavior". Journal of Management Information Systems 29 (4): 217-248.

Westen, Drew. 2007. The Political Brain: The Role of Emotion in Deciding the Fate of the Nation. New York: Public Affairs.

Wodak, Ruth. 2015. The Politics of Fear. Thousand Oaks: Sage Publications. 